\title{
As a Prelude: Bringing Melancholia to Book
}

\author{
Bernard Hœpffner
}

\section{Summary}

Democritus Junior, the alleged author of the Anatomy of Melancholy, resembles his creator, Robert Burton, in that he is melancholy. If Burton, who must have practised the art of memory, who has been called a belated survivor of the Middle Ages, and who read too many books for his own good, was melancholy, it was probably because he lived at the time when the great research libraries were being created and when the invention of the printing press led to an extraordinary proliferation of books. Democritus Junior, Robert Burton's invention, attempts to reinvent the book which the real Democritus was writing when the pseudo-Hippocrates arrived "to visite him one day in his garden at Abdera" supposedly to cure him of his alleged madness; this book, like all of Democritus's books, has not come down to us.

Keywords: melancholy; Robert Burton (1577-1640); art of memory; English Renaissance; Democritus

Democritus Junior, the supposed author of the Anatomy of Melancholy, is melancholy; thus he resembles his creator, Robert Burton (whose name appears nowhere in the book). If Burton - who must have practised the art of memory, who has been called a belated survivor of the Middle Ages and who, to use an expression dating back from my childhood, read too many books for his own good - was melancholy, it was probably because he lived at the time when the great research libraries were being created and when the invention of the printing press led to an extraordinary proliferation of books. Robert Burton's invention Democritus Junior attempts, as the former

Bernard Hœpffner, Dieugrâce, Les Bas Hubacs, F-26220 Dieulefit (bhoepffner@vallee-drome. com). 
explains to his reader, to reinvent the book which Democritus (the real Democritus) was writing when Hippocrates (the pseudo-Hippocrates) arrived "to visite him one day in his garden at Abdera" supposedly to cure him of his alleged madness - a book which, like all books by Democritus, has not come down to us.

The art of memory, as practised by Burton, might be thought to fit one of Jacques Roubaud's definitions in his L'Invention du fils de Leoprepes: "Hypothèse Camillo-2: Visée encyclopédiste; rêve de la bibliothèque-médiathèque individuelle transportable partout avec soi, sans encombrement ni investissement matériel." ${ }^{1}$ This is of course a dream whose subject is the complete mastery over knowledge - Burton as Robinson Crusoe reigning over the island of memorised knowledge. His book is arguably the last book which could reasonably claim to encompass all knowledge belonging to the Western world (although Alexander von Humboldt and Edgar Allan Poe thought they could attempt a similar task three centuries later); Burton's Anatomy was the last successful effort to cram everything into one single volume. Some twenty-five years after the first publication of Burton's book and five years after his death, a similar mind, although a much better writer and a master of rhetoric, Thomas Browne, in his Pseudodoxia Epidemica, limited his subject to vulgar errors and preferred to study nature rather than collect his arguments from memorised texts: "For what is worse, knowledge is made by oblivion, and to purchase a clear and warrantable body of Truth, we must forget and part with much we know."

According to Frances Yates, the art of memory was "put aside as an anachronism in the seventeenth century advance" , in part because of the invention of the printing press; it was not necessary to "overload" one's memory, since information was readily available in easily accessible books. Bacon, Descartes and Leibniz used memory as a tool to investigate, to scan the encyclopaedia of knowledge ... Memory ceased to be an image of the world and became a means of access to printed pages on the shelves of libraries. From Gutenberg on, from the creation of the great libraries, the content of memory changed and, instead of being loaded with volumes of texts, became a set of links, what today we would call pointers, digital addresses, i.e. links leading to the information we seek and not containing the information itself. At the beginning of the seventeenth century, memory was no longer used as the vessel containing knowledge, but was simply a tool to help discover where knowledge was stored.

1 Roubaud 1993, 73.

2 Browne 1928, 3.

3 Yates 1992, 355. 
The 13,133 quotations in the Anatomy of Melancholy seem to have come straight from Burton's memory as so many of them are faulty, although poetry of course less than prose. Burton, that cacoethes legendi, that incurable reader, quotes over 1,600 authors and over 2,700 volumes which he has read and which he remembers sufficiently well to have formed an image of the world in his chambers in Christ Church. The world of nature outside his windows holds little interest for him, and what he knows comes from his extensive reading. Without ever moving very far from Oxford, he takes us on a comprehensive tour of the known world; as a divine and a bachelor, he tells us all about love melancholy; without having examined a single patient (himself excepted), he writes a medical treatise. It could be argued that, directly or indirectly, Burton knew everything of importance about the world and man that had been written at the end of the Renaissance; he had memorised a panoptic vision of the world, which he inherited from the Ancients, the "authorities". However, he never mentions Harvey or the circulation of blood. Harvey, drawing his knowledge from nature and not only from books, had more or less destroyed the theory on which his whole book was founded, the humoural doctrines of Galen. So he ignored Harvey.

Burton lived with books, through books, amidst books; not only did he own a library containing some 2,000 volumes (10 times the average scholar's library at that time), but in addition he lived minutes away from the Bodleian Library, founded in 1602, and he was librarian of Christ Church from 1626 until his death in 1640 ("having the use of as good Libraries as ever [Jovius] had"4). If the explicit subject of the Anatomy is melancholia, the implicit theme is the book. To paraphrase Michael O'Connell, in his biography of Robert Burton ${ }^{5}$, our interest in the Anatomy of Melancholy is based largely on the fact that the book is caught in the process of digesting the immense mass of knowledge contained in libraries, of trying to master a technology still imperfectly assimilated. Burton's dilemma could be compared to ours today as we attempt to grasp the potential use of computers.

Burton's entire life was based on melancholy; we can read on his tomb the epitaph written by his brother: "Paucis notus, paucioribus ignotus, hic jacet Democritus Junior cui vitam dedit et mortem melancholia Obiit." 6 Burton wrote in his book, "I write of Melancholy, by being busie to avoid Melancholy"7. This melancholy was the illness of the English Renaissance (syphilis

\footnotetext{
4 Burton 1990, Vol. I, 3.

5 O'Connell 1986.

6 "Known to few, unknown to fewer, here lies Democritus Junior, to whom Melancholy gave life and death."

7 Burton 1990, Vol. I, 6.
} 
was at the time called the French disease); Sir William Osler called Burton's book "the greatest medical treatise written by a layman" 8 , but for Rosalie Colie it is "a structure of paradox"9 and for Stanley Fish "a self-destructive artefact" $" 10$ a slow and unstable drift through which Burton creates a literary object and to which he gives the name Democritus Junior.

Right at the beginning of his Preface, Burton announces: "To doe my selfe good I turned over such Physitians as our Libraries would afford, or my private friends impart, \& have taken this paines" 11 , he does not say, "to doe your selfe good" but "to doe my selfe good". The book was written as much (if not more) to cure the author as the reader. He has read all the physicians, all the books within his reach to find a cure for this illness; he knows the books he has read; he has them pat at his disposal: with them he would like to build his discourse. However, he tells us at the beginning of the second volume, quoting Damascenus, "that without exquisite knowledge, to worke out of bookes is most dangerous: how unsavory a thing it is to beleeve Writers, and take upon trust"

He goes even further in instilling doubts, not only concerning the usefulness of books in general but also about the very book we are reading:

And therefore (quod iterum moneo, utcunque nauseam paret lectori, malo decem verba decies repetita licet abundare, quam unum desiderari) I would advise him, that is actually melancholy, not to read this Tract of Symptomes, lest he disquiet or make himselfe for a time worse, and more melancholy then he was before ${ }^{13}$

adding that "Learning dulls and diminisheth the spirits, and so per consequens produceth melancholy"14.

This dichotomy between the declared aim of the Anatomy and Burton's statements disavowing this aim might possibly be read as a kind of joke, but that would be a terrible mistake: "one may speake in jest, and yet speake truth" 15 . Burton wants to say everything and by doing so can only contradict himself. Renaissance humanism resulted partly from the existence of thousands of copies of the same book in an invariable, canonic form. Unlike knowledge founded on memory and a relatively small number of texts passed on from one generation to the next, all books can be brought together in libraries (one could then believe that a library might contain all books), and

8 Cushing 1925, 886.

9 Colie 1945.

10 Fish 1972.

11 Burton 1990, Vol. I, 7.

12 Burton 1990, Vol. II, 17.

13 Burton 1990, Vol. I, 387 ("in consequence, I repeat, to the risk of inducing nausea in the reader, for I would rather repeat ten times the same sentences than omit anything").

14 Burton 1990, Vol. I, 302.

15 Burton 1990, Vol. I, 111. 
among them are many books which Burton has not read and some books which he has never heard of. In a library - and this is where Burton's problem lies - books can be compared:

This roving humor I have ever had, \& like a ranging Spaniell, that barkes at every bird he sees, leaving his game, I have followed all, saving that which I shoud, and may justly complaine, \& truly, [...] that I have read many Bookes, but to little purpose, for want of good method, I have confusedly tumbled over divers Authors in our Libraries, with small profit, [...] all my Treasure is in Minerva's Towre. ${ }^{16}$

Burton adopts Terentius' famous expression, "humani a me nihil alienum puto" 17 , and transforms his book into an immense and labyrinthian Borgesian library where books are the only means for grasping the reality of the world extending outside the walls and, as in Lewis Carroll's map whose scale is $1: 1^{18}$, become the whole world; everything is here, within arm's, if not within memory's reach. Thus, since the art of memory appears to have lost its usefulness in a well-ordered library, Burton has lost the mastery he thought he had over his material. He knows one does not write anything new, that all one can hope to do is to reorder inherited texts, and by reordering those texts, he would like, as one would squeeze a lemon, to increase knowledge. "A Dwarfe standing on the shoulders of a Giant may see farther then a Giant himselfe"19, says Burton after so many writers of the Renaissance; however, confronted with Borges's infinite library, with the invention of the index, he also feels that everything he writes, everything he remembers, may be checked, and then contradicted from another source, somewhere, in a book he does not know.

It is when he realises how pathetically small his (huge) memory is when compared to the volumes surrounding him that his melancholia gets worse:

What a Catalogue of new bookes all this yeare, all this age (I say) have our Franc-furt Marts, our Domesticke Marts brought out? Quis tam avidus librorum helluo, Who can read them? As already, wee shall have a vast Chaos and confusion of Bookes, we are oppressed with them, our eyes ake with reading, our fingers with turning. For my part I am one of the number, nos numerus sumus, I doe not denie it. ${ }^{20}$

Burton loves books and libraries, "And if it were so that I must be a Prisoner, if I might have my wish, I would desire to have no other Prison then that Library, and to be chained together with so many good Authors, et mortuis magistris"21. However, inside his beloved libraries, he now feels he has lost the stability which knowledge had given him. That is why - and it has frus-

16 Burton 1990, Vol. I, 4.

17 Burton 1990, Vol. III, 6 (taken from Heautontimoroumenos, I, I, 77).

18 Carroll 1893, Chap. 7.

19 Burton 1990, Vol. I, 12.

20 Burton 1990, Vol. I, 10-11.

21 Burton 1990, Vol. II, 88. 
trated numerous readers - the Anatomy of Melancholy becomes, probably despite Burton, the very example of instability (but the contrary of unbalance), each opinion being followed by another contradicting it, which is in turn followed by a commentary explaining that he does not know which to choose. We are here witnessing the transformation of the Renaissance copia into scepticism through the method itself: copia, which for the Romans meant "abundance, resources", became in the Middle Ages copiare, "comment, transcribe prolifically" and it is against the abundance of resources that Burton stumbles, although he certainly gave us an abundance of fair copy.

Devon Hodges said that

\begin{abstract}
Anatomy and melancholy have an affinity; they are both an effect of loss - the loss of meaning, the loss of any clear path to the truth, the loss of power to master an uncertain world. [...] A melancholy sense that something is lost propels a desire to conduct an anatomy - and anatomy itself creates loss. Anatomy then is a cure for melancholy that creates the conditions that produce it. No wonder that Burton endlessly writes his Anatomy of Melancholy. ${ }^{22}$
\end{abstract}

It is with humour that Burton himself indicates this contradiction which pulls him into an endless ratiocination (the uroboros, the snake with its tail in its mouth, the prototype of the vicious circle):

As that Gymnosophist in Plutarch, made answere to Alexander, (demanding which spake best) Every one of his fellows did speak better then the other: so may I say of these causes; to him that shall require which is the greatest, every one is more grievous then other, and this of Passion the greatest of all. ${ }^{23}$

This paradox is visible everywhere: numerous chapters end not with a conclusion but with a list of authors and books to consult, so many " \&c." $(2,452)$ indicating that no conclusion can be reached. The complex structure of the work shows that the order of Burton's arguments is neither hierarchical nor productive of value judgement, but is simply the order his memory has imposed on them: "I have mingled Sacra prophanis, but I hope not prophaned, and in repetition of Authors names, ranked them per accidens, not according to Chronologie; sometimes Neotericks before Antients, as my memory suggested" 24 , and "Memory, layes up all the species which the senses have brought in, and records them as a good Register, that they may be forthcomming when they are called for by Phantasie and Reason"25; to quote Michael O'Connell, "The library is simply too rich for the search to end prematurely; it allows us to come to no definite conclusions" 26 .

22 Hodges 1985, 121.

23 Burton 1990, Vol. I, 246.

24 Burton 1990, Vol. I, 19.

25 Burton 1990, Vol. I, I, 152.

26 O’Connell 1986, 48. 
The printing press necessarily meant that at some point the writer had to decide that his book was complete, that it could be handed over to the printer who would transform it into a canonical entity: the same text could then be read by thousands of people. But for writers like Burton or Montaigne, writing was almost an end in itself; they had one book in them, one book only, and until their death this book could, should and had to be expanded, corrected. Although Montaigne and Burton wrote from opposite points of view - Montaigne's subject was himself ("Ce sont icy mes fantasies, par lesquelles je ne tasche point à donner à connoistre les choses, mais moy"27) and he ended portraying humanity as a whole, while Burton's subject was humanity ("My subject is of Man, and humane kind. Thou thy selfe art the subject of my Discourse") and he ended by portraying himself - and although Montaigne can be seen as centripetal and Burton as centrifugal, both authors left us one and only one book to which they continually added. CD-ROMs, Internet and hypertext would have been the perfect medium for the Essays as well as for the Anatomy of Melancholy.

Books, printed books, books by the thousands, books everywhere: their infinite number seems to have increased Burton's melancholy humour. Books, however, together with a few simples and the laugh he inherited from Democritus, were also his remedy. Today, after an intake of "serotonin reuptake inhibitors" 28 , after talk therapy, who would write such a monster of a book? Books are the prison around Burton, books are also his windows onto the world; words are what he throws at the iron bars of this prison, all the while building one of the sturdiest bars to imprison his readers further. Among the most famous readers who were willing to let themselves be shut inside this Minerva's Tower, we find Johnson, Sterne (in whose library sat enthroned Rabelais, Montaigne, Cervantes, Burton and Thomas Browne), Milton, Locke, Swift, Keats, Byron, Melville (who, in the first sentence of his first published text, "Fragments from a Writing-Desk", mentions the chair on which Burton sat), not forgetting modern authors such as Guy Davenport, Samuel Beckett, and especially Borges, who started me on a lifetime of reading Burton and who seems to be the kernel from which most of my reading has sprung. Thus, in contemptuous defiance of the paradox which lies at the centre of the Anatomy of Melancholy, there is no reason why we should not go on reading this book as one of the best remedies against melancholy written by one of the most melancholy of writers, and as a magnificent study of the world, the world as it was then described in books, the world in which 
Burton lived. Might not the image of the world given to us by science during the last four centuries be only one of the possible images of it? In that case, wouldn't an image of the world such as the one Burton tried to build still be somehow valid today? At any rate, I think he has given us, with Democritus Junior's Anatomy of Melancholy, the image of a world as it is being constructed, far from static, rigid and frozen in time. Language, the uninterrupted flow of words poured by Burton onto his pages, is his own antidote against melancholy. But that is another matter altogether.

\section{Bibliography}

Browne, Thomas, Pseudodoxia Epidemica, Vol. 2 (London 1928)

Burton, Robert, Anatomy of Melancholy (Oxford 1990)

Carroll, Lewis, Sylvia and Bruno Concluded (London 1893)

Colie, Rosalie, Paradoxia Epidemica: The Renaissance Tradition of Paradox (Princeton 1945)

Cushing, Harvey, The Life of Sir William Osler (Oxford 1925)

Fish, Stanley, Self-Consuming Artefacts: The Experience of Seventeenth-Century Literature (Berkeley 1972)

Hodges, Devon, Renaissance Fictions of Anatomy (Amherst 1985)

Montaigne, Michel de, Les essais (Paris 1950)

O’Connell, Michael, Robert Burton (Boston 1986)

Roubaud, Jacques, L'Invention du fils de Leoprepes (Strasbourg 1993)

Smith, Jeremy, Where the Roots Reach for Water (New York 1999)

Yates, Frances A., The Art of Memory (London 1992) 